\title{
Vocal Symptoms and Associated Risk Factors between Male and Female University Teachers
}

\author{
Gustavo Polacow Korn ${ }^{1}$ Sung Woo Park ${ }^{1}$ Antonio Augusto de Lima Pontes ${ }^{1}$ Paulo Pontes ${ }^{1}$ \\ 1 Department of Otorhinolaryngology and Head and Neck Surgery, \\ Universidade Federal de São Paulo, SP, Brazil \\ Address for correspondence Gustavo Polacow Korn, Departamento de \\ Otorrinolaringologia e Cirurgia de Cabeça e Pescoço, Universidade \\ Federal de São Paulo, Rua Pedro de Toledo, 947, São Paulo, \\ Int Arch Otorhinolaryngol 2018;22:271-279. \\ SP, 04532-000, Brazil (e-mail: gustavokorn@uol.com.br).
}

\begin{abstract}
Introduction Many recent studies on teachers warn of the adverse effects that voice problems have on work performance. However, only a few of these studies included university teachers.

Objective To compare the vocal symptoms and risk factors between male and female university teachers in a private institution within the city of São Paulo.

Methods In a cross-sectional survey, a voice self-evaluation form prepared by the Ministry of Labor in Brazil was administered to 846 university teachers at a private institution in the city of São Paulo.

Results The percentage of hoarseness, vocal tract discomfort, neck pain and foreign body sensation was significantly higher in female than in male subjects. A significantly higher percentage of males participated in other professional activities in addition to teaching, reported working in a calm environment compared with working in a moderately or severely tense and stressful environment, and rated themselves as calm, slightly stressed and anxious or moderately stressed and anxious rather than very stressed and anxious. A significantly higher percentage of females spent most of their time teaching compared with performing other professional activities, and rated themselves as chatty or impulsive.

Keywords

- dysphonia

- risk factors

- faculty

Conclusion Among university teachers, a significantly higher percentage of females than males reported hoarseness, vocal tract discomfort, neck pain and foreign body sensation. Some risk factors related to work organization, workplace environment, voice care and quality of life variables were related to this higher prevalence in females.
\end{abstract}

\section{Introduction}

Many recent studies on teachers warn of the adverse effects that voice problems have on work performance, ${ }^{1,2}$ and suggest a high risk of work-related vocal problems. ${ }^{1,3,4}$ However, only a few of these studies included university teachers. ${ }^{5,6}$ University teachers should be studied as a single group because they may exhibit high levels of social and cultural uniformity ${ }^{5,6}$ since they are a homogeneous group (for instance, university teachers subject to the same work

received

September 9, 2016

accepted

August 10, 2017

published online

October 26, 2017 shifts at a single institution, under the same environmental conditions, in a single city).

To evaluate functional dysphonia in a professional voice user, the term occupational dysphonic syndrome (ODS) ${ }^{7}$ was developed, which includes five symptoms: (1) hoarseness, (2) pain or irritation in the throat (vocal tract discomfort), (3) neck pain, (4) foreign body sensation, and (5) clearing of the throat.

In a systematic review, Cantor Cultiva et $\mathrm{al}^{8}$ found a wide variation in the prevalence of voice disorders and suggested

Copyright $\odot 2018$ by Thieme Revinter Publicações Ltda, Rio de Janeiro, Brazil 
that this variation may be due to the use of generic terms such as 'vocal complaints' and 'vocal symptoms' to describe these disorders. Thus, it is of interest to use the voice selfevaluation form reformulated by the Ministry of Labor in Brazil, which examines each ODS symptom, to obtain an epidemiological profile of vocal complaints and risk factors in a university setting. ${ }^{5,6}$

Recently, we performed two studies to assess the presence of risk factors for specific vocal symptoms, for example, hoarseness and vocal tract discomfort, among 846 university teachers at a private institution using a self-evaluation form prepared by the Brazilian Ministry of Labor. ${ }^{9}$ In the first study, we concluded that university teachers have a high prevalence of hoarseness (39.6\%) and that factors such as teaching time, female gender, work organization, noise and sound competition in the work environment, air pollution and stress and anxiety in the work environment, tension, personal habits and lifestyle/quality of life are related to the presence of hoarseness in this population. ${ }^{5}$ In the second study, ${ }^{6}$ we concluded that university teachers have a high prevalence of vocal tract discomfort (50.8\%) and identified related factors, which included female gender, age ( $\leq 60$ years), time-consuming professional activities, noise and sound competition in the workplace, air pollution-related stress and anxiety, access to free water, care or medication used for the voice, seeking a doctor's care for the symptom, the degree of teaching difficulty in terms of use of voice within and outside the workplace, tension, stress and anxiety.

We hypothesized that females have more vocal symptoms than males and sought to determine whether there are differences in the risk factors for voice problems between the genders.

In this study, a previously published voice self-evaluation form $^{5,6}$ was used to identify differences in the five symptoms (hoarseness, vocal tract discomfort, neck pain, foreign body sensation and clearing of the throat) between males and females and the associated risk factors in a sample of university teachers.

The objective of this study was to compare the vocal symptoms and risk factors between male and female university teachers in a private institution within the city of São Paulo.

\section{Methods}

This cross-sectional study was reviewed and authorized by the Research Ethics Committee of the Universidade Federal de São Paulo (354.895/2013) from which the data were collected.

Voice self-evaluation forms, which were prepared by the Ministry of Labor in Brazil, were completed within a onemonth period in 2007 by 846 university teachers working in various positions at a single private institution in the city of São Paulo. Teachers from this single private institution were recruited. The response rate was $86 \%$.

Of the 846 university teachers, $49.8 \%$ were male and $46.5 \%$ female. Gender information was not available for $3.8 \%$ of the teachers.
Data on five vocal symptoms (hoarseness, vocal tract discomfort, neck pain, foreign body sensation and clearing of the throat) and risk factors were compiled from the completed self-evaluation forms. The risk factor variables were categorized into groups as follows:

- Identification variables: age and teaching time.

- Work organization variables: number of institutions employed at (some teachers work at more than one institution), maximum workload during the week, class length, time between classes, maximum number of students per classroom, participation in other professional activities (for example, many teacher have other professional activities such as working for a law firm, or as an engineer) and participation in time-consuming professional activities (more time teaching, which means more vocal use or other activity that demands less vocal use).

- Workplace variables: noise in the classroom, air pollution, stress and anxiety related to a specific activity, and water supply at the institution.

- Vocal symptoms: hoarseness, vocal tract discomfort, neck pain, foreign body sensation, clearing of the throat.

- Voice care variables: use of medication for the throat or voice, medical consultations made for vocal symptoms, and degree of vocal difficulty during teaching.

- Personal habits and lifestyle/quality of life outside the institution: voice use (in and out of the workplace), stress and anxiety, water consumption/hydration habits, diet, body weight, smoking habits, alcohol consumption, use of other drugs, continuous use of medication, physical activity, and health care.

The aim of this paper was to compare the different variables of the genders of university teachers to the search variables. To test for differences in numerical variables between genders, we used Student $t$-tests, and to test for differences in categorical variables, we used chi-square tests. Where appropriate, Fisher exact test or the likelihood ratio test was used. In the comparisons of the variables with more than two categories, multiple comparisons corrected by the Bonferroni method (comparisons among categories two by two) were used only in the variables in which the result of the test was significant. A significance level of $5 \%$ ( $p$-value $<0.05$ ) was used.

\section{Results}

\section{Identification Variables}

The percentage of males was higher in teachers $>60$ years of age than in teachers $\leq 60$ years of age ( - Fig. $\mathbf{1}$ ). The mean age (and standard deviation) was higher in male $(42.9 \pm 10.4)$ than female $(41.2 \pm 9.6)$ subjects.

No significant difference in teaching time was observed between the genders (-Table $\mathbf{1}$ ).

\section{Work Organization Variables}

No significant differences were observed between the genders for the variables 'number of institutions where you teach', 'maximum workload during the work week', 'duration 


\section{Age range $(p=0.001)$}

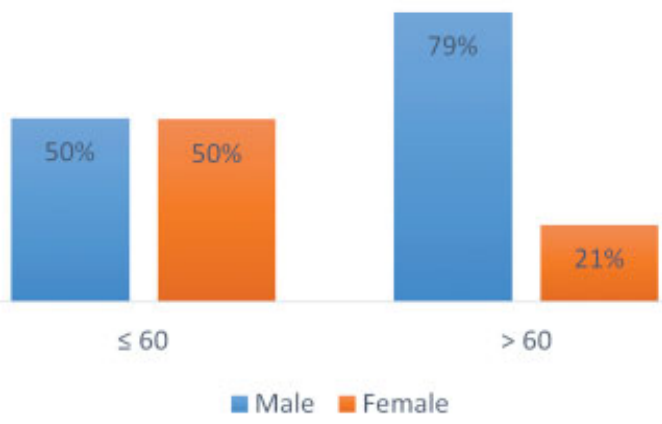

Fig. 1 Comparison of the genders by age range.

of the most frequent classes', and 'minutes of break time' (-Table 2).

In terms of the maximum number of students per classroom, the percentage of females with maximum students between 51 and 100 was significantly lower than teachers with less than 30 students or between 31 and 50 students (-Table 2).

The percentage of males was significantly higher among teachers with other professional activities than teaching (-Table 2).

The percentage of females was significantly higher among teachers who spent most of their time teaching than among those who spent most of their time performing other professional activities ( - Table 2 ).

\section{Workplace Variables}

The percentage of males was significantly higher among teachers who considered the workplace to be a calm environment compared with those who considered the workplace as a moderately or highly tense and stressful environment, $p=0.018$ e $p=0.049$, respectively (-Fig. 2 ).

No significant differences were observed between the genders for the variables 'noise in the classroom', 'air pollution', and 'water supply at the institution' ( - Table 3 ).

\section{Voice Symptoms and Voice Care Variables}

The percentages of hoarseness, vocal tract discomfort, neck pain and foreign body sensation were all significantly higher for females than for males (-Fig. 3, 4, 5 and $\mathbf{6}$ ).

No significant differences were observed between the genders for the variable 'clearing of the throat' ( - Table 4).

The percentage of females was significantly higher among those teachers who generally underwent care or took medication for the throat or voice than among those who did not; similarly, the percentage of females was higher among those teachers who sought medical advice for the throat or voice than among those who did not (-Table 4).

The percentage of males was lower among those teachers who did not experience any difficulty teaching than among those who did experience moderate difficulty teaching because of their vocal problems, $p=0.049$ ( - Fig. 7).

\section{Personal Habits and Lifestyle/Quality of Life Variables} In terms of voice quality within and/or outside the workplace, the percentage of females was significantly higher among teachers who were chatty or impulsive than among those who were communicative or introspective (-Table 5 ). In terms of tension, stress and anxiety, the percentage of females was significantly higher among teachers who were very stressed and anxious than male teachers. Female teachers represented a significantly lower percentage among teachers who were calm or slightly stressed (-Table 5).

In terms of body weight, the percentage of females was significantly higher among those teachers who described themselves as lean or at the ideal weight and the percentage of males was significantly higher among those teachers who described themselves as slightly overweight or obese (-Table 5).

A significantly higher percentage of males than of females was observed for each of the variables alcohol consumption and physical activity (-Table $\mathbf{6}$ ).

No significant differences were observed between the genders for the variables 'water/hydration', 'diet', 'smoking', 'use of other drugs', 'continuous-use medication', and 'health care' (-Table 5 and $\mathbf{6})$.

Table 1 Comparison of teaching time between the genders (Chi-square test)

\begin{tabular}{|l|l|l|l|l|}
\hline Gender & $\begin{array}{l}\text { Male } \\
\mathbf{n}(\%)\end{array}$ & $\begin{array}{l}\text { Female } \\
\mathbf{n}(\%)\end{array}$ & $\begin{array}{l}\text { Total } \\
\mathbf{n}(\%)\end{array}$ \\
\hline \multicolumn{5}{|l|}{} \\
\hline Teaching tenure & $13(54.2)$ & $11(45.8)$ & $24(100)$ & 0.467 \\
\hline In 1 year or less & $109(54)$ & $93(46)$ & $202(100)$ & \\
\hline Between 1 and 5 years & $135(54.9)$ & $111(45.1)$ & $246(100)$ & \\
\hline Between 5 and 10 years & $105(46.9)$ & $119(53.1)$ & $224(100)$ & \\
\hline Between 10 and 20 years & $55(50.9)$ & $53(49.1)$ & $108(100)$ & \\
\hline More than 20 years & $417(51.9)$ & $387(48.1)$ & $804(100)$ & \\
\hline Total &
\end{tabular}


274 Vocal Symptoms and Associated Risk Factors between University Teachers Korn et al.

Table 2 Comparison of the genders regarding work organization variables

\begin{tabular}{|c|c|c|c|c|}
\hline Gender & $\begin{array}{l}\text { Male } \\
\text { n (\%) }\end{array}$ & $\begin{array}{l}\text { Female } \\
\mathrm{n}(\%)\end{array}$ & $\begin{array}{l}\text { Total } \\
\text { n (\%) }\end{array}$ & $p$-value \\
\hline \multicolumn{5}{|c|}{ Number of institutions where you teach } \\
\hline 1 & $196(47.7)$ & $215(52.3)$ & $411(100)$ & 0.059 \\
\hline 2 & $157(55.7)$ & $125(44.3)$ & $282(100)$ & $\begin{array}{l}\text { Chi-square } \\
\text { test }\end{array}$ \\
\hline 3 & $48(53.3)$ & $42(46.7)$ & $90(100)$ & \\
\hline More than 3 & $19(67.9)$ & $9(32.1)$ & $28(100)$ & \\
\hline Total & $420(51.8)$ & $391(48.2)$ & $811(100)$ & \\
\hline \multicolumn{5}{|c|}{ Maximum workload during the work week } \\
\hline $\begin{array}{l}1 \text { to } 3 \\
\text { class hours per } \\
\text { day }\end{array}$ & $70(51.1)$ & $67(48.9)$ & $137(100)$ & 0.734 \\
\hline $\begin{array}{l}4 \text { to } 6 \\
\text { class hours per } \\
\text { day }\end{array}$ & $174(54)$ & $148(46)$ & $322(100)$ & $\begin{array}{l}\text { Chi-square } \\
\text { test }\end{array}$ \\
\hline $\begin{array}{l}6 \text { to } 8 \\
\text { class hours per } \\
\text { day }\end{array}$ & $102(50.5)$ & $100(49.5)$ & $202(100)$ & \\
\hline $\begin{array}{l}\text { More than } 8 \\
\text { class hours per } \\
\text { day }\end{array}$ & $74(49)$ & $77(51)$ & $151(100)$ & \\
\hline Total & $420(51.7)$ & $392(48.3)$ & $812(100)$ & \\
\hline \multicolumn{5}{|c|}{ Duration of the most frequent classes in the workday } \\
\hline 40 minutes & $13(56.5)$ & $10(43.5)$ & $23(100)$ & 0.643 \\
\hline 50 minutes & $203(49.8)$ & $205(50.2)$ & $408(100)$ & $\begin{array}{l}\text { Chi-square } \\
\text { test }\end{array}$ \\
\hline 60 minutes & $23(57.5)$ & $17(42.5)$ & $40(100)$ & \\
\hline 100 minutes & $93(51.7)$ & $87(48.3)$ & $180(100)$ & \\
\hline $\begin{array}{l}\text { More than } \\
100 \text { minutes }\end{array}$ & $89(56)$ & $70(44)$ & $159(100)$ & \\
\hline Total & $421(52)$ & $389(48)$ & $810(100)$ & \\
\hline \multicolumn{5}{|c|}{ Minutes of class breaks usually granted } \\
\hline Less than 20 & $385(50.9)$ & $372(49.1)$ & $757(100)$ & 0.077 \\
\hline 20 to 30 & $33(67.3)$ & $16(32.7)$ & $49(100)$ & $\begin{array}{l}\text { Likelihood } \\
\text { ratio test }\end{array}$ \\
\hline More than 30 & $3(50)$ & $3(50)$ & $6(100)$ & \\
\hline Total & $421(51.8)$ & $391(48.2)$ & $812(100)$ & \\
\hline \multicolumn{5}{|c|}{ Maximum number of students per classroom } \\
\hline $\begin{array}{l}\text { Fewer than } 30 \\
\text { students }\end{array}$ & $10(33.3)$ & $20(66.7)$ & $30(100)$ & $0.028^{*}$ \\
\hline $\begin{array}{l}31 \text { to } 50 \\
\text { students }\end{array}$ & $84(45.9)$ & $99(54.1)$ & $183(100)$ & $\begin{array}{l}\text { Likelihood } \\
\text { ratio test }\end{array}$ \\
\hline $\begin{array}{l}51 \text { to } 100 \\
\text { students }\end{array}$ & $254(55.9)$ & $200(44.1)$ & $454(100)$ & \\
\hline $\begin{array}{l}101 \text { to } 150 \\
\text { students }\end{array}$ & $67(48.9)$ & $70(51.1)$ & $137(100)$ & \\
\hline $\begin{array}{l}\text { More than } 150 \\
\text { students }\end{array}$ & $4(66.7)$ & $2(33.3)$ & $6(100)$ & \\
\hline Total & $419(51.7)$ & $391(48.3)$ & $810(100)$ & \\
\hline \multicolumn{4}{|c|}{ Fewer than 30 students $\times 31$ to 50 students } & 1.000 \\
\hline \multicolumn{4}{|c|}{ Fewer than 30 students $\times 51$ to 100 students } & $0.048^{*}$ \\
\hline \multicolumn{4}{|c|}{ Fewer than 30 students $\times 101$ to 150 students } & 1.000 \\
\hline \multicolumn{4}{|c|}{ Fewer than 30 students $\mathrm{x}$ more than 150 students } & 1.000 \\
\hline \multicolumn{4}{|c|}{31 to 50 students $\times 51$ to 100 students } & $0.049^{*}$ \\
\hline
\end{tabular}

\section{Discussion}

Most of the vocal symptoms (hoarseness, vocal tract discomfort, neck pain and foreign body sensation) in our study of university teachers were more prevalent in females than in males, which is consistent with the studies by Russell et $a l,{ }^{10}$ Marçal and Peres, ${ }^{11}$ Van Houtte et al, ${ }^{2}$ Van Houtte et al, ${ }^{12}$ de Jong et al., ${ }^{13}$ and Nerrière et al, ${ }^{14}$ which included

\section{Workplace in terms of tension, stress and ansiety $(p<0.001)$}
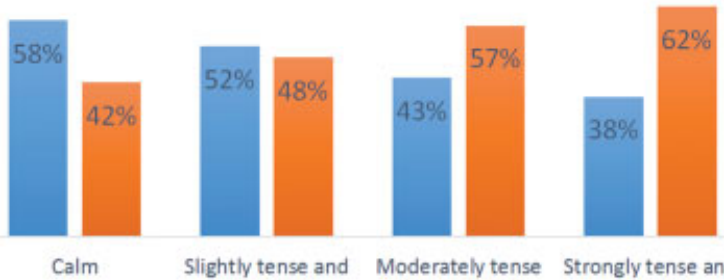
stressful and stressful stressful

- Male armale

Fig. 2 Comparison of the genders by stress and anxiety in the workplace. 
Table 3 Comparison of the genders in terms of workplace variables (Chi-square test)

\begin{tabular}{|c|c|c|c|c|}
\hline Gender & $\begin{array}{l}\text { Male } \\
\text { n (\%) }\end{array}$ & $\begin{array}{l}\text { Female } \\
\text { n (\%) }\end{array}$ & $\begin{array}{l}\text { Total } \\
\text { n (\%) }\end{array}$ & $p$-value \\
\hline \multicolumn{5}{|l|}{ Workplace in terms of noise and sound competition } \\
\hline Quiet and adequate (comfortable) & $64(58.7)$ & $45(41.3)$ & $109(100)$ & 0.072 \\
\hline Slightly noisy (tolerable) & $249(53.3)$ & $218(46.7)$ & $467(100)$ & \\
\hline Uncomfortably noisy (disturbing) & $99(46.3)$ & $115(53.7)$ & $214(100)$ & \\
\hline Highly noisy (intolerable) & $6(35.3)$ & $11(64.7)$ & $17(100)$ & \\
\hline Total & $418(51.8)$ & $389(48.2)$ & $807(100)$ & \\
\hline \multicolumn{5}{|l|}{ Workplace in terms of air pollution } \\
\hline Clean, cool and airy (comfortable) & $177(52.2)$ & $162(47.8)$ & $339(100)$ & 0.079 \\
\hline Slightly polluted, hot, cold, windy or muffed (disturbing) & $194(54.6)$ & $161(45.4)$ & $355(100)$ & \\
\hline Moderately polluted, hot, cold, windy or muffed (disturbing) & $45(42.5)$ & $61(57.5)$ & $106(100)$ & \\
\hline Highly polluted, hot, cold, windy or muffed (intolerable) & $3(30)$ & $7(70)$ & $10(100)$ & \\
\hline Total & $419(51.7)$ & $391(48.3)$ & $810(100)$ & \\
\hline \multicolumn{5}{|l|}{ Water at ease and easily accessible } \\
\hline Yes & $339(51.4)$ & $320(48.6)$ & $659(100)$ & 0.662 \\
\hline No & $76(53.9)$ & $65(46.1)$ & $141(100)$ & \\
\hline Total & $415(51.9)$ & $385(48.1)$ & $800(100)$ & \\
\hline
\end{tabular}

Vocal tract discomfort $(p<0.001)$

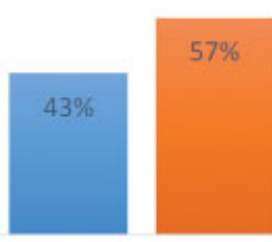

Yes

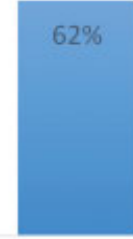

No

a Male aremale

Fig. 3 Comparison of the genders by the presence of vocal tract discomfort.

\section{Foreign body sensation}

$$
(p=0.003)
$$

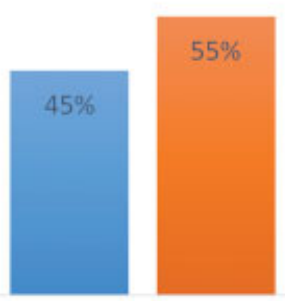

Yes

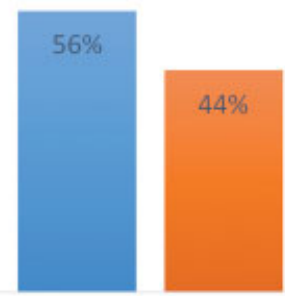

No

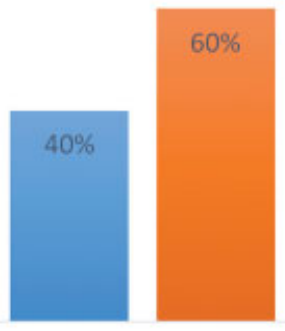

Yes

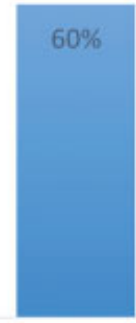

No

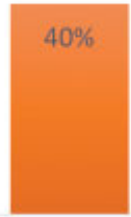

wale w Female

Fig. 5 Comparison of the genders by the presence of neck pain.

\section{Hoarseness $(p<0.001)$}

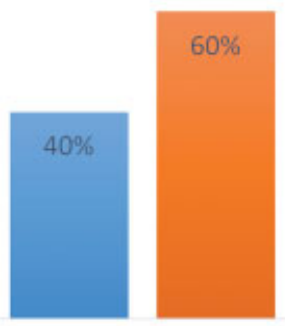

Yes

Male Female

Fig. 6 Comparison of the genders by the presence of hoarseness.
Fig. 4 Comparison of the genders by the presence of foreign body sensation. 
Table 4 Comparison of the genders in terms of symptoms variables (Chi-square test)

\begin{tabular}{|l|l|l|l|l|}
\hline Gender & $\begin{array}{l}\text { Male } \\
\mathbf{n}(\%)\end{array}$ & $\begin{array}{l}\text { Female } \\
\mathbf{n}(\%)\end{array}$ & $\begin{array}{l}\text { Total } \\
\mathbf{n}(\%)\end{array}$ & p-value \\
\hline \multicolumn{5}{|l|}{ Some care or medication for the throat or voice } \\
\hline No & $320(55.1)$ & $261(44.9)$ & $581(100)$ & $0.006^{*}$ \\
\hline Yes & $95(43.8)$ & $122(56.2)$ & $217(100)$ & \\
\hline Total & $415(52)$ & $383(48)$ & $798(100)$ & \\
\hline Medical advice sought for voice symptoms & \\
\hline Yes & $51(34.7)$ & $96(65.3)$ & $147(100)$ & $<0.001^{*}$ \\
\hline No & $337(55.3)$ & $272(44.7)$ & $609(100)$ & \\
\hline Total & $388(51.3)$ & $368(48.7)$ & $756(100)$ & \\
\hline Clearing of the throat \\
\hline Yes & $177(54.6)$ & $147(45.4)$ & $324(100)$ & 0.195 \\
\hline No & $231(49.7)$ & $234(50.3)$ & $465(100)$ & \\
\hline Total & $408(51.7)$ & $381(48.3)$ & $789(100)$ & \\
\hline
\end{tabular}

teachers from kindergarten, primary, secondary, elementary, middle and high school.

In general, females have a higher rate of benign vocal pathologies and a higher rate of voice disorders. ${ }^{15-17}$ The female larynx has a predisposition to vocal fold injury, which may be explained by the higher fundamental frequency compared with the male larynx, ${ }^{18}$ by the incomplete posterior glottis closure and by the glottis proportion. ${ }^{19}$

\section{Degree of difficulty in teaching due to vocal problems $(p=0.030)$}

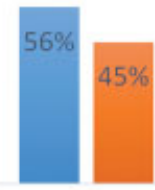

None - no difficulty, full use of the voice

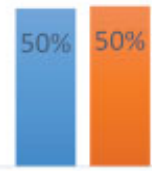

Mild-minimal disruption or limitation in the use of the voice

\section{wale n Female}

Fig. 7 Comparison of the genders by the degree of teaching difficulty due to vocal problems.

While acknowledging the female predisposition to vocal fold injury, it is important to identify other potential gender predispositions to voice disorders. ${ }^{20}$ We aimed to determine whether any other variables, including work organization, workplace, voice care, personal habits and lifestyle/quality of life variables, could also account for the higher prevalence of ODS symptoms in females.

A higher percentage of male than female teachers engaged in other professional activities, which usually demand less vocal use than teaching activities do. In addition, the percentage of female professionals who spend most of the time teaching was higher than the corresponding percentage of males. Therefore, there are work organization variables that

Table 5 Comparison of the genders regarding other variables (Chi-square test)

\begin{tabular}{|c|c|c|c|c|}
\hline \multirow[t]{2}{*}{ Gender } & Male & Female & Total & p-value \\
\hline & $\mathrm{n}(\%)$ & n (\%) & n (\%) & \\
\hline \multicolumn{5}{|c|}{ In terms of voice inside and/or outside the work place, you qualify as a person who: } \\
\hline Speaks little (introvert) & $32(71.1)$ & $13(28.9)$ & $45(100)$ & $<0.001^{*}$ \\
\hline Speaks moderately (communicative) & $305(58)$ & $221(42)$ & $526(100)$ & Chi-square \\
\hline Speaks a lot (chattering) & $73(35.4)$ & $133(64.6)$ & $206(100)$ & test \\
\hline Speaks too much (impulsive) & $10(30.3)$ & $23(69.7)$ & $33(100)$ & \\
\hline Total & $420(51.9)$ & $390(48.1)$ & $810(100)$ & \\
\hline \multicolumn{4}{|c|}{ Speaks little (introvert) x Speaks moderately (communicative) } & 0.516 \\
\hline \multicolumn{4}{|c|}{ Speaks little (introvert) x Speaks a lot (chattering) } & $<0.001^{*}$ \\
\hline \multicolumn{4}{|c|}{ Speaks little (introvert) x Speaks too much (impulsive) } & $0.002^{*}$ \\
\hline \multicolumn{4}{|c|}{ Speaks moderately (communicative) x Speaks a lot (chattering) } & $<0.001^{*}$ \\
\hline \multicolumn{4}{|c|}{ Speaks moderately (communicative) x Speaks too much (impulsive) } & $0.012^{*}$ \\
\hline \multicolumn{4}{|c|}{ Speaks a lot (chattering) x Speaks too much (impulsive) } & 1.000 \\
\hline \multicolumn{5}{|c|}{ In terms of stress and anxiety, you qualify as a person who is: } \\
\hline Calm & $122(60.7)$ & $79(39.3)$ & $201(100)$ & $0.002^{*}$ \\
\hline Slightly tense and stressful & $179(51)$ & $172(49)$ & $351(100)$ & Chi-square \\
\hline
\end{tabular}


Table 5 (Continued)

\begin{tabular}{|c|c|c|c|c|}
\hline \multirow[t]{2}{*}{ Gender } & Male & Female & Total & $p$-value \\
\hline & $\mathrm{n}(\%)$ & $n(\%)$ & $n(\%)$ & \\
\hline Moderately tense and stressful & $97(49.7)$ & $98(50.3)$ & $195(100)$ & test \\
\hline Strongly tense and stressful & $21(33.3)$ & $42(66.7)$ & $63(100)$ & \\
\hline Total & $419(51.7)$ & $391(48.3)$ & $810(100)$ & \\
\hline \multicolumn{4}{|l|}{ Calm x Slightly tense and stressful } & 0.168 \\
\hline \multicolumn{4}{|l|}{ Calm x Moderately tense and stressful } & 0.168 \\
\hline \multicolumn{4}{|l|}{ Calm $x$ Strongly tense and stressful } & $0.001^{*}$ \\
\hline \multicolumn{4}{|c|}{ Slightly tense and stressful x Moderately tense and stressful } & 1.000 \\
\hline \multicolumn{4}{|c|}{ Slightly tense and stressful x Strongly tense and stressful } & $0.048^{*}$ \\
\hline \multicolumn{4}{|c|}{ Moderately tense and stressful $x$ Strongly tense and stressful } & $0.049^{*}$ \\
\hline \multicolumn{5}{|c|}{ In terms of drinking water/hydration, you qualify as a person who: } \\
\hline $\begin{array}{l}\text { Drinks a few liquids (forgets or } \\
\text { does not feel thirsty, and urinates } \\
\text { less than } 3 \text { times/day) }\end{array}$ & $66(45.8)$ & $78(54.2)$ & $144(100)$ & 0.177 \\
\hline Drinks moderately ( 1 to $2 \mathrm{~L}$ a day) & $238(52.5)$ & $215(47.5)$ & $453(100)$ & Likelihood \\
\hline Drinks a lot (More than $2 \mathrm{~L}$ a day) & $114(54.5)$ & $95(45.5)$ & $209(100)$ & ratio test \\
\hline $\begin{array}{l}\text { Drinks excessively (the need to } \\
\text { urinate is frequent and it bothers } \\
\text { you) }\end{array}$ & $1(20)$ & $4(80)$ & $5(100)$ & \\
\hline Total & $419(51.7)$ & $392(48.3)$ & $811(100)$ & \\
\hline \multicolumn{5}{|c|}{ In terms of diet, you qualify as a person who: } \\
\hline $\begin{array}{l}\text { Eats little (fastens or eats less than } \\
3 \text { meals a day) }\end{array}$ & $70(62.5)$ & $42(37.5)$ & $112(100)$ & 0.099 \\
\hline Eats moderately (eats 3 meals a day) & $289(49.7)$ & $292(50.3)$ & $581(100)$ & Likelihood \\
\hline $\begin{array}{l}\text { Eats a lot (does not control gluttony } \\
\text { and realizes that you abuse it a bit) }\end{array}$ & $54(50.9)$ & $52(49.1)$ & $106(100)$ & ratio test \\
\hline $\begin{array}{l}\text { Eats excessively (the stomach feels } \\
\text { full and/or you are losing control) }\end{array}$ & $5(55.6)$ & $4(44.4)$ & $9(100)$ & \\
\hline Total & $418(51.7)$ & $390(48.3)$ & $808(100)$ & \\
\hline \multicolumn{5}{|c|}{ In terms of body weight, you qualify as a person who is: } \\
\hline Lean (underweight) & $14(45.2)$ & $17(54.8)$ & $31(100)$ & $<0.001^{*}$ \\
\hline At the ideal weight & $130(42.1)$ & $179(57.9)$ & $309(100)$ & Chi-square \\
\hline Slightly overweight & $234(56.8)$ & $178(43.2)$ & $412(100)$ & test \\
\hline Obese (very overweight) & $41(70.7)$ & $17(29.3)$ & $58(100)$ & \\
\hline Total & $419(51.7)$ & $391(48.3)$ & $810(100)$ & \\
\hline $\begin{array}{l}\text { Lean (underweight) x At the ideal } \\
\text { weight }\end{array}$ & & & & 1.000 \\
\hline $\begin{array}{l}\text { Lean (underweight) x Slightly } \\
\text { overweight }\end{array}$ & & & & 1.000 \\
\hline $\begin{array}{l}\text { Lean (underweight) x Obese } \\
\text { (very overweight) }\end{array}$ & & & & $0.048^{*}$ \\
\hline $\begin{array}{l}\text { At the ideal weight x Slightly } \\
\text { overweight }\end{array}$ & & & & $<0.001^{*}$ \\
\hline $\begin{array}{l}\text { At the ideal weight } x \text { Obese } \\
\text { (very overweight) }\end{array}$ & & & & $<0.001^{*}$ \\
\hline $\begin{array}{l}\text { Slightly overweight x Obese } \\
\text { (very overweight) }\end{array}$ & & & & 0.264 \\
\hline
\end{tabular}


Table 6 Comparison of the genders regarding other variables

\begin{tabular}{|c|c|c|c|c|}
\hline Gender & $\begin{array}{l}\text { Male } \\
\text { n (\%) }\end{array}$ & $\begin{array}{l}\text { Female } \\
\text { n (\%) }\end{array}$ & $\begin{array}{l}\text { Total } \\
\text { n (\%) }\end{array}$ & $p$-value \\
\hline \multicolumn{5}{|l|}{ Cigarettes (tobacco) } \\
\hline Yes & 61 (54.5) & $51(45.5)$ & $112(100)$ & 0.910 \\
\hline No & $220(52.8)$ & $197(47.2)$ & $417(100)$ & Chi-square test \\
\hline Former smoker & $74(51.7)$ & $69(48.3)$ & $143(100)$ & \\
\hline Total & $355(52.8)$ & $317(47.2)$ & $672(100)$ & \\
\hline \multicolumn{5}{|l|}{ Alcohol use } \\
\hline Yes & $167(68.2)$ & $78(31.8)$ & $245(100)$ & $<0.001^{*}$ \\
\hline No & $248(45.8)$ & $293(54.2)$ & $541(100)$ & Chi-square test \\
\hline Total & $415(52.8)$ & $371(47.2)$ & $786(100)$ & \\
\hline \multicolumn{5}{|l|}{ Other drugs } \\
\hline No & $389(52.2)$ & $356(47.8)$ & 745 (100) & 1.000 \\
\hline Yes & $3(50)$ & $3(50)$ & $6(100)$ & Fisher exact test \\
\hline Total & $392(52.2)$ & $359(47.8)$ & $751(100)$ & \\
\hline \multicolumn{5}{|c|}{ Continuous-use medication } \\
\hline No & $298(52.9)$ & $265(47.1)$ & $563(100)$ & 0.343 \\
\hline Yes & $111(48.9)$ & $116(51.1)$ & $227(100)$ & Chi-square test \\
\hline Total & $409(51.8)$ & $381(48.2)$ & $790(100)$ & \\
\hline \multicolumn{5}{|l|}{ Physical activity } \\
\hline No & $174(47)$ & $196(53)$ & $370(100)$ & $0.019^{*}$ \\
\hline Yes & $240(55.6)$ & $192(44.4)$ & $432(100)$ & Chi-square test \\
\hline Total & $414(51.6)$ & $388(48.4)$ & $802(100)$ & \\
\hline \multicolumn{5}{|c|}{ In terms of health care, you consider yourself as being: } \\
\hline Absent-minded & $78(51.7)$ & $73(48.3)$ & $151(100)$ & 0.817 \\
\hline Controlled/cautious & $285(50.2)$ & $283(49.8)$ & $568(100)$ & Likelihood ratio test \\
\hline Concerned & $42(56)$ & $33(44)$ & $75(100)$ & \\
\hline Alarmed & $2(50)$ & $2(50)$ & $4(100)$ & \\
\hline Total & $407(51)$ & $391(49)$ & $798(100)$ & \\
\hline
\end{tabular}

place females at a higher risk of vocal symptoms compared with males.

The female teachers considered the workplace environment to be more tense and stressful than males did. Furthermore, the female subjects experienced more difficultly teaching because of their vocal problems than did the male subjects.

However, the percentage of females was higher than the percentage of males among those teachers who take care or medication for the throat or voice and among those who sought medical advice. This treatment-seeking behavior is in accordance with the results of Van Houtte et al. ${ }^{2}$

In studies of professional voice users, it is important to consider vocal use both in and out of the workplace. In the present study, the females spoke more frequently than the males, and they qualified themselves as more tense and stressed than did the males. Nerrière et $\mathrm{al}^{14}$ found an association between psychological distress and voice issues.
Unfortunately, a cross-sectional dataset such as ours does not allow us to distinguish causes and consequences.

In this study, more females described themselves as leaner than males. The males reported more alcohol consumption and physical activity relative to the females. We speculate that heavier weights and higher levels of alcohol consumption could be associated with laryngopharyngeal reflux symptoms, such as foreign body sensation. In this study, we did not evaluate a reflux finding score. However, we speculate that this symptom is not exclusive of reflux.

This study emphasizes the recognition of vocal symptoms in university teachers, and treatment and prevention for these symptoms in this population is warranted. These symptoms in professionals must be investigated and acknowledged, especially in females.

To reduce variation among individuals in the interpretation of the self-evaluation survey, we surveyed cultural, social, and regional viewpoints in a homogeneous group 
(for instance, university teachers subject to the same work shifts at a single institution under the same environmental conditions in a single city).

Limitations to this study include the sampling from a single institution. Therefore, these data cannot be generalized to university professors from around Brazil. Future directions in this line of research include the characterization of vocal symptoms in another group of professional voice users.

\section{Conclusion}

Among university teachers, significantly higher percentages of females than males reported hoarseness, vocal tract discomfort, neck pain and foreign body sensation. Some risk factors related to work organization, workplace environment, voice care and quality of life variables were linked to a higher prevalence in females.

\section{References}

1 Roy N, Merrill RM, Thibeault S, Parsa RA, Gray SD, Smith EM. Prevalence of voice disorders in teachers and the general population. J Speech Lang Hear Res 2004;47(02):281-293

2 Van Houtte E, Claeys S, Wuyts F, Van Lierde K. The impact of voice disorders among teachers: vocal complaints, treatment-seeking behavior, knowledge of vocal care, and voice-related absenteeism. J Voice 2011;25(05):570-575

3 Smith E, Gray SD, Dove H, Kirchner L, Heras H. Frequency and effects of teachers' voice problems. J Voice 1997;11(01):81-87

4 Behlau M, Zambon F, Guerrieri AC, Roy N. Epidemiology of voice disorders in teachers and nonteachers in Brazil: prevalence and adverse effects. J Voice 2012;26(05):665.e9-665.e18

5 Korn GP, Augusto de Lima Pontes A, Abranches D, Augusto de Lima Pontes P. Hoarseness and risk factors in University teachers. J Voice 2015;29(04):518.e21-518.e28

6 Korn GP, Augusto de Lima Pontes A, Abranches D, Augusto de Lima Pontes P. Vocal tract discomfort and risk factors in University teachers. J Voice 2016;30(04):507.e1-507.e8
7 de Almeida SIC, Pontes P. Dysphonic occupational syndrome: new aspects of this nosological entity. Arq Int Otorrinolaringol 2010; 14(03):346-350

8 Cantor Cutiva LC, Vogel I, Burdorf A. Voice disorders in teachers and their associations with work-related factors: a systematic review. J Commun Disord 2013;46(02):143-155

9 Ministry of Labor and Employment (BR). Labor Office in the State São Paulo SDT 1 North/SP. Occupational dysphonia program in teachers. São Paulo, BR: Labor Office in the State of São Paulo, Security Section and Health Worker; 2003

10 Russell A, Oates J, Greenwood KM. Prevalence of voice problems in teachers. J Voice 1998;12(04):467-479

11 Marçal CC, Peres MA. Self-reported voice problems among teachers: prevalence and associated factors. Rev Saude Publica 2011; 45(03):503-511

12 van Houtte E, Claeys S, Wuyts F, van Lierde K. Voice disorders in teachers: occupational risk factors and psycho-emotional factors. Logoped Phoniatr Vocol 2012;37(03):107-116

13 de Jong FI, Kooijman PG, Thomas G, Huinck WJ, Graamans K, Schutte HK. Epidemiology of voice problems in Dutch teachers. Folia Phoniatr Logop 2006;58(03):186-198

14 Nerrière E, Vercambre MN, Gilbert F, Kovess-Masféty V. Voice disorders and mental health in teachers: a cross-sectional nationwide study. BMC Public Health 2009;9(01):370

15 Coyle SM, Weinrich BD, Stemple JC. Shifts in relative prevalence of laryngeal pathology in a treatment-seeking population. J Voice 2001;15(03):424-440

16 Herrington-Hall BL, Lee L, Stemple JC, Niemi KR, McHone MM. Description of laryngeal pathologies by age, sex, and occupation in a treatment-seeking sample. J Speech Hear Disord 1988; 53(01):57-64

17 Zhukhovitskaya A, Battaglia D, Khosla SM, Murry T, Sulica L. Gender and age in benign vocal fold lesions. Laryngoscope 2015;125(01):191-196

18 Titze IR. Physiologic and acoustic differences between male and female voices. J Acoust Soc Am 1989;85(04):1699-1707

19 Pontes P, Kyrillos L, Behlau M, De Biase N, Pontes A. Vocal nodules and laryngeal morphology. J Voice 2002;16(03):408-414

20 Hunter EJ, Tanner K, Smith ME. Gender differences affecting vocal health of women in vocally demanding careers. Logoped Phoniatr Vocol 2011;36(03):128-136 